Book Review

ISSN: 2162-3104 Print/ ISSN: 2166-3750 Online Volume 7 Number 1 (2017), pp. 160-162

(c) Journal of International Students http://jistudents.org/

\title{
Exploring the Social and Academic Experiences of International Students in Higher Education Institutions
}

Bista, K., \& Foster, C. (2016). Exploring the social and academic experiences of international students in higher education institutions. Hershey, PA: IGI Global, pp. 363; \$185.00 (hardback), ISBN13: 978-14666-9749-2

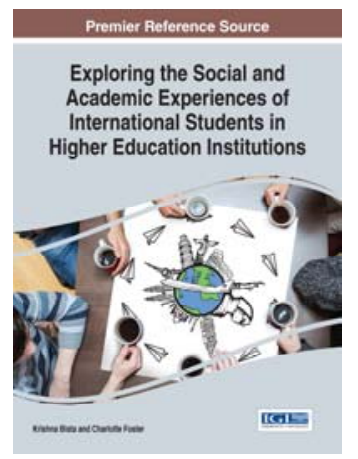

Reviewed by

Sherrie Lee, University of Waikato, New Zealand

This edited book explores the multifaceted experiences of international students in higher education. With an increasing presence of international students in universities across the globe, there is a need for a greater awareness of such a diverse student population. Although the studies in this book are mostly based in North American educational settings, the range of topics reflects important ongoing and emerging issues.

Academic acculturation is a major theme that is addressed throughout the book. In particular, several chapters focus on the experiences of groups of undergraduate or postgraduate students. Chapter One examines the experiences of eight postgraduate students in a US university, while Chapter Three investigates the experiences of 20 undergraduates in a New Zealand university. The interview studies of these chapters reveal how inadequate English proficiency and cultural differences hamper international students' learning opportunities and their ability to form meaning relationships with their domestic peers. In Chapter Ten, focus group discussions revealed a need for ESL curriculum to be discipline-specific, as well as to support students' communicative competence in social settings. Chapter Nine examines international teaching assistants in relation to mentoring efforts and strategies provided by their departments. The authors found that many teaching assistants desired explicit mentoring approaches, 
especially when they were not familiar with cultural norms and teaching methods.

Other chapters explore the dynamics of intercultural interactions between international and domestic students. Chapter Two focuses on the dynamics of intercultural interactions among international and domestic postgraduate students at a Canadian university. Through in-depth interviews with ten students, the authors found a lack of interest among domestic students about their international classmates. In response, international students sought solidarity and support from fellow international students. Chapter Fourteen describes a two-year ethnographic study which tracked the study experiences of two Japanese students enrolled in the same teaching training program. The combination of observations, multiple interviews and reflective field notes produce a compelling narrative of how faculty members had low academic expectations of the students. As a result, faculty failed to address students' academic weaknesses and limited their professional development. The author also showed that cultural dominance and White superiority impacted teaching practices in this study.

Race, ethnicity and identity are prominent themes that emerged in this text. While racial discourses are frequent in the US, international students often have different ways of understanding the concepts of race, ethnicity and identity, and how these concepts apply to them. Chapter Four explores how students' conceptions of racial terms such as 'Black' and 'White' were experienced in their home countries and how they perceived and experienced these racial concepts in a US educational institution. Chapter Five deals with a similar topic but focuses exclusively on the experiences of African students and how they negotiate the racial identity of 'Black', in particular, Black racial solidarity. The authors found that the African students shared the perspective of the common fate for Black people but nonetheless perceived themselves as distinct from native-born Blacks in the US.

The theme of racial discourse is further explored through the topics of neo-racism and racial stereotypes. Chapter Eleven focuses on participants from sub-African and Caribbean countries. Using the lenses of selfdetermination theory and neo-racism, the authors found that while students had high levels of motivation to succeed academically, their domestic peers did not readily recognize those strengths, potentially because of negative media coverage of the countries from where the students came from. Chapter Eight examines East Asian students' racial stereotypes and experiences in their social relations. The authors found that students had a strong notion of racial hierarchy in which 'White' people were at the top, followed by 'East Asian', 'Latino', African-Americans' and 'Southeast Asian'. While there were instances of positive interactions with domestic 
students, racial prejudices and limited interactions with other racial groups were predominant.

An important but neglected aspect of the international student experience is the experience of their partners. While partners are a valuable source of social and emotional support to international students, they themselves face adjustment issues. Chapters Six and Seven focus on the experiences of the partners of international students at North American universities. The authors show how structural factors such as visa conditions and institution policies contribute to the partners' sense of isolation and a lack of purpose in life. The authors also recommend changes and policies and practices that increase recognition and support for students' partners.

The remaining chapters in the book focus on the use of large-scale survey data to inform institutional support of international students. Chapter Twelve reviews how the International Student Barometer, a US campuswide survey regarding student satisfaction and students' overall experience, has been used with other sources of data to initiate changes in institutional practices and ultimately improve internationalization efforts to benefit all students. Chapter Thirteen examines the differences in academic achievements of different cohorts of US undergraduates - first-time freshmen, exchange visitors, and international transfer undergraduates from community colleges. Such demographic data is useful for informing admission policies and targeting increased student support at appropriate groups of students.

Finally, Chapter Fifteen provides a multi-institutional large-scale survey showing how international students' participation in high-impact educational practices was positively associated with their academic engagement and academic skills development. There is no doubt about the complexities and challenges of enhancing international students' experiences as illustrated throughout the preceding chapters. Nonetheless, the final chapter signals a positive and forward-looking attitude towards successful intervention and support.

The book provides a variety of perspectives to understand the diversity of the experiences of international students. Faculty, researchers, administrators and policy makers will find this book a useful resource for guiding institutional changes and future research.

SHERRIE LEE is a $\mathrm{PhD}$ candidate at the Faculty of Education at the University of Waikato. Her research focuses on academic learning practices of international students using an ethnographic approach. She completed her Master of Arts in Teaching (TESOL) at the University of Southern California and was formerly a business communications lecturer at a polytechnic in Singapore. E-mail: csl15@students.waikato.ac.nz 